\title{
PURPOSEFUL EFFORT IN OUR SOCIAL EVOLUTION ${ }^{1}$
}

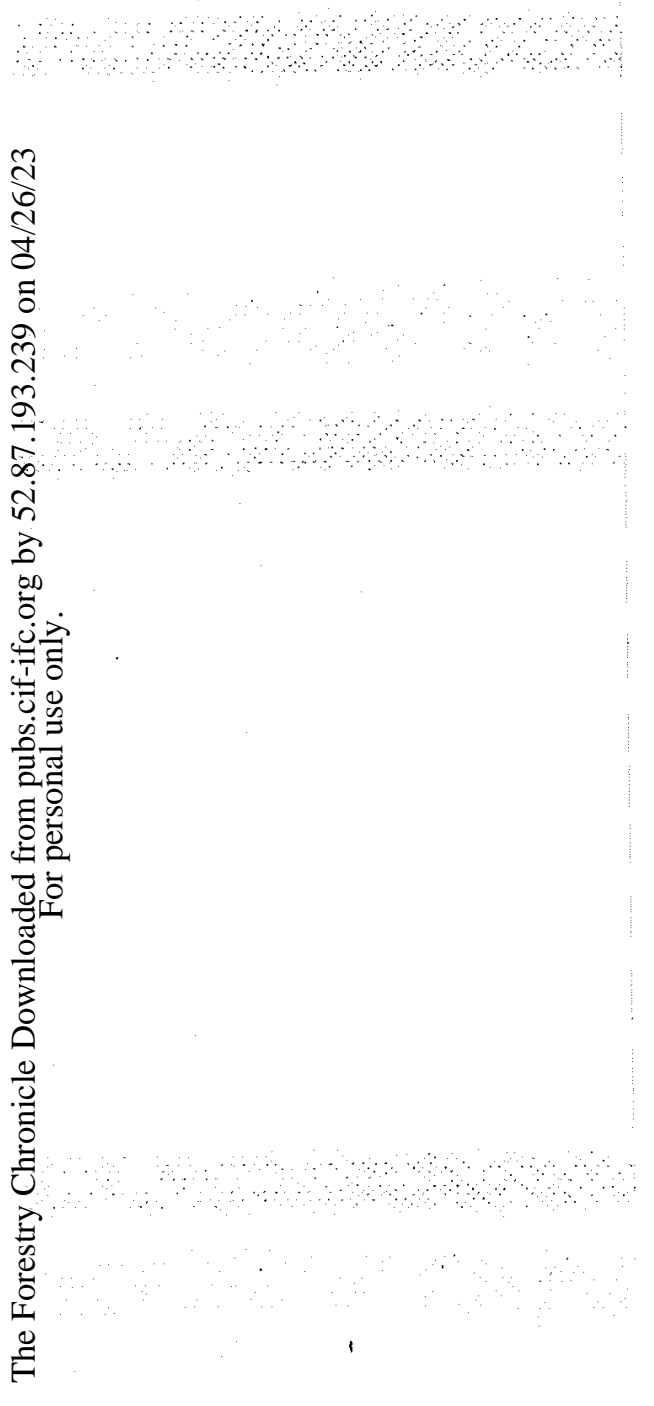

BY DR. M. M. COADY

\section{St. Francis Xavier University, Antigonish, Nova Scotia \\ Christlan democratic FORMula}

"What are we going to do with Canada?" is a pertinent question for every Canadian citizen to ask himself. It is especially appropriate for the members of your organization. You are, as I shall indicate later on, connected with a phase of the development of Canadian natural resources that has an allimportant role in our future civilization. What use shall we make of the products of our seas, our forests, our soil and our mines? They have a lot to do, perhaps everything to do, with the kind of society we are going to build. The monuments that the people who now inhabit this piece of earth called Canada will leave behind them are going to be the indices of our civilization. The vastness of the country and the greatness of these resources should point the way to a great civilization. Our manifest destiny, therefore, is to be great.

But the Canadian challenge is greater than this. Other people in other times have built great civilizations, too, but many of them have passed away. According to Toynbee, 14 of the 19 civilizations recorded in human history have ceased to be. The Canadian challenge is not only to be great, but to be enduringly great. We have the opportunity as perhaps few other countries in the world to build a great civilization and at the same time to immunize it against decay. Probably the historic moment has arrived when peoples like the Canadians, profiting by the successes and mistakes of past history, can set up a social order that will be a perpetual crescendo of life, not for five or six hundred years like Greece and Rome and other countries, but one which will endure with undiminished splendor as long as men live in this land.

The democratic Christian formula by which this could be done, we always believed, was voluntary human action in a free society. Nature itself demands such action. The real dynamics for this human action comes from the belief in religion which postulates the Fatherhood of God and the Brotherhood of Man. It stems from the dignity of man, founded on the existence of God and man's brotherhood through Redemption in Christ. From this springs the idea of control and self-discipline and the decencies that are the preservatives of human society. This is the old democratic formula of the good life.

This idea of human life has been challenged in one way or another for many centuries. First in the modern age came the elimination of religion and the exaltation of science. This gave us a reversion to type and in the very country that was most scientific produced a Hitler and the other diabolically abnormal creatures of our day. Simultaneously with this attack on the democratic formula came the philosophy that life was mainly a scramble for the attainment of wealth. Financial success was made the goal of human effort. Great modern nations, our own included, under the dynamic of this idea plundered the natural resources with reckless abandon for the pure fun of amassing great fortunes that in many cases were later on spent in riotous

1. This is a summary of Dr. Coady's inspirational address at the annual banquet of the C.S.F.E., Toronto, October 25, 1949. 
living. These unbalanced philosophies threw up millions of dissatisfied people all over the world and finally the democratic formula itself was called into question. New schemes involving force were adopted to solve human problems. This gave us Facism, Nazism, Communism and the terrible cataclysms that have rocked the earth in recent decades. All these schemes are oversimplifications. The good and abundant life is too difficult and too complex a thing to be arrived at by any simple formula of force. All these efforts at solving social problems are distinctly unscientific. Reason goes out where force comes in. There is no man nor combination of men wise enough to blueprint the evolution of human society in detail. Man's nature and the nature of society will determine what we shall do. The chemist in the laboratory doesn't hold up a test tube in one hand and a gun in the other and say to the chemicals that they must turn red or he will shoot. If he is a scientist he will be satisfied with what the natural forces give him.

\section{CAUSE OF OUR PLIGHT}

The terrible doctrines of our time which seem to destroy all the things we cherish are in strange contrast with the scientific spirit of the modern age. One would suspect that it would be impossible for such crude philosophies to get any credence in our time. The whole thing is so much out of harmony with science and reason that it points to the conclusion that evil spirits are roaming through the world today. "An enemy hath done this," as the Scripture says. The real answer can be had in the fact that we had a democratic formula but never really applied it. We have permitted ourselves to float down the river of events hoping that we would land in a haven of prosperity. Enough people did land in material prosperity by this philosophy to give them the complacency that has bedevilled the world. If we are to give the good and abundant life to all the people, we must put purposeful effort in life. This means knowledge, science, investigation, research. There must be intellectual prospectors everywhere in the land. But it is not good enough that this knowledge be confined to a few specially favored people. The great masses must be let in on this knowledge. This is highly important if we are to use the great natural resources of this country to build a lasting civilization. The people must know where we are going. They must enthuse over the possibility of using our natural resources for great human ends.

THE COMING AGE OF WOOD

The phase of Canadian life in which your Society is particularly interested is a fine exemplification of the value of the democratic formula. Knowledge, science, pays great dividends. Malthus, years ago, frightened the world with the idea that since the human race was growing in geometric ratio and the food resources of the earth were being depleted, the day was fast coming when there would be universal famine. The neo-Malthusians of our day have resurrected this spectre. There can be no doubt that there is grave danger of food shortage. If we go on plundering the earth as we did in the past, we will certainly come to grief. We cannot ignore the warnings of great men like Lord Orr, Vogt and Osborne. But we can change our ways and we are actually doing so. The forests of the world are one of the great answers to this perplexing question. Glesinger in his fascinating book, "The Coming 
Age of Wood", points out that the scientific use of the forests of the world will enable us to triple the standard of living of the whole human race. Pretty nearly everything that man needs, under the magic wand of science, can come from wood. This achievement should send a new thrill through the whole world. When we were young we killed every snake we met because there was a tradition that it was connected with hell. When we were young bad boys our tendency was to chop down every tree in sight just for the fun of knocking it down. Whole nations of bad boys like the people of the United States and our own people in recent times, want to chop down every last tree on the American continent for the fun of making money. This scientific discovery about the place of wood in modern civilization changes our whole attitude. Trees are now sacred things. Even the old forbidding spruce tree has a new dignity. We feel like planting trees everywhere on the side hills, on the waste lands, in the nooks and corners where nothing can conveniently grow. This new, scientific discovery will set us all off on a great crusade of planting billions of trees. They will give us a new standard of living; they will give us the waters that will put fish in the sea; they, nature's great manufacturing plants, will give us new soil; they will prevent floods and land erosions and give us the kind of climate that God intended for our section of the world.

What can be said of wood and forests can also be said of the products of the sea and the land. Science will yield great dividends. But this can't be done if only a few people know about it. We cannot carry out any program for the proper use and conservation of natural resources if the great masses of the people don't know about it. Not only must they know about it but they must enter into the spirit of it. They must feel that the whole thing is their cause, that it is their life.

\section{Adult EdUCATION}

To build this kind of a Canadian citizenship we need a universal, effective scheme of adult education. To be sure we need formal education both in elementary and in high schools but this type of education only prepares the people for the real phase of education which is the education of adult life. Continuous adult learning is necessary for the proper exploration of our great natural resources.

But let us not fool ourselves. It is not easy to get the Canadian people or any other people mobilized for continuous adult learning. If anybody thinks that this can be done by a program of mere academic education, they are doomed to disappointment. The masses of our people are not going to be long interested in just mere academic learning. If we are realists we will parallel this program of education with a program of social and economic activities. The people's thinking must issue in action. I am realistic and materialistic enough, if you will, to believe that their thinking must pay. This will come about when they have a new participation in the economic processes of society. They will take an interest like all humans do in the things that pay them dividends. Tell them, for instance, that the Canadian forests, that the Canadian seas, are their forests and their seas and they will be interested in getting knowledge about how to explore and exploit them. 


\section{THE ZONE IDEA}

We can't mobilize the Canadian people for any such great undertaking by working first in the national theatre. As a matter of fact, we cannot educate the "Canadian people" as such because that phrase "Canadian people" is an abstraction. We can educate the people of particular communities, particular regions, and zones. If we are going to be practical we will break up Canada into its natural zones and organize the people of these zones for educational and social purposes. There are five such natural zones in Canada - the Maritime Provinces, Quebec, Ontario, the Prairie Provinces and the Far West. If the people of these zones, bound together as they are by common social, economic and political conditions, can be organized for educational work, then their federation will give us a national movement. The national movement can be federated with other national movements and we will get a world movement. In this way we could finally organize the whole human race for that enlightenment which will precede the one world which we all desire and to the creation of which we should bend all our energies. The feasibility of this procedure has been demonstrated by the work which we at St. Francis Xavier University have been carrying on for twenty years in the Maritime Provinces. We went out twenty years ago to organize the people-all the people both in urban and rural communities, all the people of every vocational group irrespective of racial origin or religious faith. We asked every possible agency to work with us and we pledged ourselves to co-operate with every other agency and to eliminate as much as possible duplication of effort. The results of these efforts have been highly satisfactory. Some one hundred thousand people and probably nearly that many families out of the million and a quarter of our population are enrolled in one way or another in this movement. We want to be modest about our achievements but we really feel that a new golden era is in the offing for Eastern Canada. We welcome into this movement our new province of Newfoundland. We know that if we can release the energies of the people on worthwhile activities, Canadian civilization will be as good or better than anything that has yet appeared.

A Canadian people enlightened by such a program will have a new concept of life. Not only will they themselves have a new consciousness of destiny, but they will see a new purpose in the natural resources of this great country, Canada, which by an inscrutable Providence they now inhabit. The plants and animals in the fields, the fish in the sea, the trees in the forests, and the metals in the earth, will have a destiny too. From now on they will be sacred things created for man's use. This tender regard and respect for life in plants and animals will breed culture and peace. When we learn to treat the things of the earth in a reverent manner and not use them for evil purposes, then probably, we will begin to have a tender regard for our fellow human beings everywhere on the earth. The refining influence of this attitude towards the material things of the earth may well lay the foundation for human fellowship and lasting peace. 